\title{
Evaluation of Guidelines for PPICC: Purpose and Processing on Ideation and Creative Innovations for Competency Innovator
}

\author{
Piyanun Klaichun', Pratoomtong Trirat ${ }^{2}$, Chulalak Sorapan ${ }^{3}$, Nipachcha Rojratanavanit ${ }^{4}$, \\ Seksan Sakonthawat ${ }^{5}$ \\ ${ }^{1}$ School of Creative Educational Management, Panyapiwat Institute of Management \\ ${ }^{2}$ Suriyadhep Teachers College, Rangsit University \\ ${ }^{3}$ Faculty of Education, Sukhothai Thammathirat Open University, \\ ${ }^{4}$ Faculty of Education, Chulalongkorn University \\ ${ }^{5}$ Montfort College Primary Section \\ 11p.klaichun@gmail.com, ${ }^{2}$ dhanit33@gmail.com, ${ }^{3}$ chulalak.stou@gmail.com, ${ }^{4}$ nipachcha.r@chula.ac.th, ${ }^{5}$ sakesarn@ gmail.com
}

\begin{abstract}
This research was aimed to 1) determine the current and desirable states, and the priority needs index for PPICC: Purpose and Processing on Ideation and Creative Innovations for Competency Model. Mixed methods research was employed and undertaken in 2 phrases. Phase 1 investigated the model. The qualitative research approach to multiple case study collected data from 2 case studies in order to provide a profound understanding of the subject being investigated and allow for applying the research results to similar context. Phrase 2 investigated the priority needs index for PPICC: Purpose and Processing on Ideation and Creative Innovations for Competency Model. Phase 2 utilizing interviews with 30 experts in human resource development, digital technology, and education administration. Instruments comprise structured questionnaires, guidelines propriety, and feasibility evaluation form. Analyses involve descriptive statistics i.e. frequency, percentage, mean, and standard deviation, PNI Modified, and content analysis.

Results of the evaluation of Phase 1 investigated the model was PPICC: Purpose and Processing on Ideation and Creative Innovations for Competency. Results of the evaluation of Phase 2 investigated that the overall of current and desirable states are at a moderate and highest level, respectively. The highest values of priority need index elements are as follows: The first priority need index fell on Discovery Skill of Ideation Innovations is Creative Mind. Professional Teachers found Skill for Collaboration and problem- solving creative skill, Creating Innovations is to Put to other Use, Goals of successful factors for the development of instructors to have different characteristics are Inspirer, Environment management for learning and teaching found that procurement, resource support, and learning resources for the development of the students to be innovative. Processing is Establish University. Discovery Skill of Ideation Innovations is Creative Mind. Competency Innovator found that Ideation in learning and teaching management found that - build interaction in learning through connection and networking, and the least is Purpose which is Stamina. Therefore, an important mechanism for the development of innovative skills must come from the cooperation of the public sector, the private sector, educational institutes, and the family institute to develop skills, knowledge and ability to keep pace with today's world effectively.
\end{abstract}

Index Terms

PPICC: Purpose and Processing on Ideation and Creative Innovations for Competency Model, Creative Innovations, Competency Innovato

Article Received: 10 August 2020, Revised: 25 October 2020, Accepted: 18 November 2020

\section{Introduction}

Developing innovations in which the main goal is new value and differentiation of innovations. All sectors of the economy emphasize the importance of innovation, businesses, governments, and organizations. The aim is to find innovative employees who have the ability to cooperate in developing and creating new innovations to build competitiveness and innovation. Innovative individuals are a vital resource and higher education is a key factor in human capital development [1][2][3], and higher education institutions should take into account of preparing innovative individuals according to the needs in the 21 st century [4][5]. The master plan has reformed the country to step into the era of Thailand 4.0 that focuses on development in many areas which are setting goals for quality graduates to create and apply operational knowledge to meet the needs of the organization to be able to compete internationally, setting goals that aim to develop graduates into thinkers and able to create innovation by linking with the private and industrial sectors in collaboration with work integrated learning, innovation and business [6]. To Produce graduates that are innovative in the field of educational management to attract students' interest and create an understanding in order to produce graduates to acquire the knowledge, understanding and perspectives in educational management that will be needed to produce graduates who will be creative in the field they study for innovation development for the students' benefits in various fields such as commercial innovation (The Shear Team). Educational management should focus on developing learners and workforce with skills and characteristics that are ready to meet the needs of all sectors. The goal should be to produce manpower into the labor market rather than education based on the availability of educational institutions as at present. Therefore, a guideline for teaching and learning should enhance the ability to produce graduates that are suitable for the current social and technological conditions according to the model for creating innovators at the tertiary level by analyzing the current situation and changing trends affecting the education of the nation based on the fact and important issues affecting education management in higher education. 
Setting guidelines that are consistent with the model for enhancing innovation in university graduates production is the process of driving the production of graduates to have the characteristics of innovation of Thai society and ready to compete in the future world society.

\section{Objectives}

Determine the current and desirable states, and the priority needs index for PPICC: Purpose and Processing on Ideation and Creative Innovations for Competency Model.

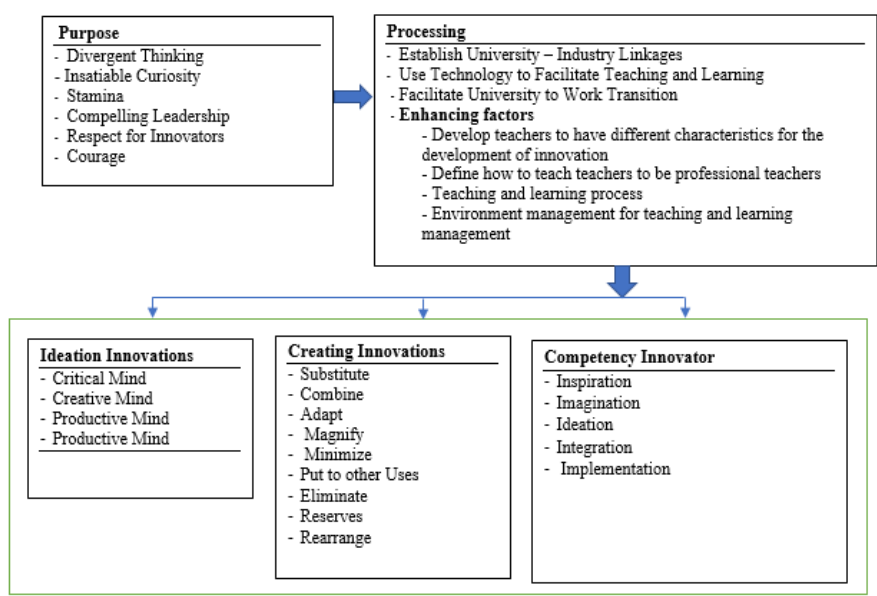

Model: PPICC: Purpose and Processing on Ideation and Creative Innovations for Competency Innovator

\section{Research Methodology}

Mixed methods research was employed and undertaken in 2 phases. Phrase 1 investigated the model. The qualitative research approach to multiple case study collected data from 2 case studies in order to provide profound understanding about the subject being investigated and allow for applying the research results to similar context. Phase 2 investigated the priority needs index for PPICC: Purpose and Processing on Ideation and Creative Innovations for Competency Model. Phase 2 samples are by means of interviews with 30 experts of human resource development, digital technology, and education administration. Instruments comprise structured questionnaire, and guidelines propriety and feasibility evaluation form. Analyses involve descriptive statistics i.e. frequency, percentage, mean, and standard deviation, PNI Modified, and content analysis.

Phase 1

Step 1 Study concepts, theories and research related to the development of innovation for undergraduate programs at private universities by studying concept, theory, research, concept of innovation and enhancement of innovation. Concepts of educational management at the bachelor level; Discovery Skill, Design Thinking and Types of Innovators from domestic and international academic documents and research domestic and 1) (Chickering's Theory of Student Development) [7]. Concepts for research consists of development potential in seven areas which are 1) Developing Competence 2) Managing Emotion 3) Moving Through Autonomy Toward Interdependence 4) Developing Mature Interpersonal Relation 5) Establishing Identity 6) Developing Purpose 7) Developing Integrity 2) Concept for Innovators according to Kylliäinen [8] proposes concepts for creating innovation in six types which are 1) Seek Out
Problems 2) Choose Problems That Suit Capabilities, Strategy And Culture 3) Identify The Innovation Strategies Most Likely to Solve the Problems 4) Leverage Platforms to Access Ecosystems of Talent, Technology and Information 5) Build A Collaborative Culture 6) Understand That Innovation Is a Messy Business 3) Concept of design thinking process derived from the concept of De School [9][10] which proposes that design thinking process consists of 5 process which are 1) Empathize 2) Define 3) Ideate 4) Prototype and 5) Test 4) Concept for Discovery Skill from concepts of Dyer, Gregersen, and Christensen regarding skills to seek and find creativity (Discovery Skill) which consists of 5 skills namely 1) Associating 2) Questioning 3) Observing 4) Experimenting and 5) Networking [11]

Phase 2

Step 1 Bring the target model and innovative thinking process towards innovation competency PPICC: Purpose and Processing on Ideation and Creative Innovations for Competency Innovator and conduct structured interviews with 30 experts.

Step 2 Current and desirable states and the priority needs index of PPICC: Purpose and Processing on Ideation and Creative Innovations for Competency Innovator

\section{Research Findings}

Current and desirable states of PPICC: Purpose and Processing on Ideation and Creative Innovations for Competency Innovator model found that 7 approaches, 24 sub-approaches, and 6 procedures:

Current State of Purpose Setting found that overall level is high $(\overline{\mathrm{X}}=3.526$, S.D. $=0.90)$ when considered on each side respectively as follows: Insatiable Curiosity, Stamina, Compelling Leadership, Respect for Innovators, Courage, Divergent Thinking.

Current State of Processing found that the overall level is moderate $(\overline{\mathrm{X}}=3.456$, S.D. $=0.80)$ and when considered each side respectively as follows: Use Technology to Facilitate Teaching and Learning, Establish University Industry Linkages, Facilitate University to Work Transition).

Current State of Discovery Skill found that the overall level is moderate $(\overline{\mathrm{X}}=3.225$, S.D. $=0.76)$ Ideation Innovations and when considered each side respectively as follows: Creative Mind, Critical Mind, Productive Mind, Productive Mind.

Current State of Creating Innovations found that the overall level is moderate $(\overline{\mathrm{X}}=3.225$, S.D. $=0.76)$ and when considered each side respectively as follows: Put to other Uses, Combine, Substitute, Magnify, Minimize, Eliminate, Reserves, Adapt, Rearrange.

Current State of Competency Innovator found that the overall level is moderate $(\overline{\mathrm{X}}=3.125$, S.D. $=0.66)$ and when considered each side respectively as follows: Imagination, Inspiration, Ideation, Integration, Implementation.

Current State of Goals of successful factors for the development of innovation undergraduate courses in private universities found that overall result was at a moderate level $(\overline{\mathrm{X}}=3.225$, S.D. $=0.78)$ and when considered each side respectively as follows:

Develop teacher for Professional Teachers was at a 
moderate level $(\overline{\mathrm{X}}=3.220$, S.D. $=0.56)$ and when considered each side respectively as follows: Inspirer, Advocate, Confidant, Friend, Mentor, Leader, Illumination. Professional Teachers was at a moderate level $(\overline{\mathrm{X}}=3.220$, S.D. $=0.56)$ and when considered each side respectively as follows: Subject matt and Pedagogical Knowledge, Skill for Collaboration and problem- solving creative skill, Learning Teaching and Assessment methods.

Learning and teaching management overall result was at a moderate level $(\overline{\mathrm{X}}=3.355$, S.D. $=0.76)$ and when considered each side respectively as follows: Create interaction in learning through connection and networking Create a fun learning concept - Create an assessment model that reflects the results - Create strengthening and supporting factors.

Learning processes for the management of the environment for teaching and learning. overall result was at a moderate level $(\overline{\mathrm{X}}=3.220$, S.D. $=0.74)$ and when considered each side respectively as follows: - Develop teachers to have different characteristics for the development of innovationDefine how to teach teachers to be professional teachers teaching and learning process -Environment management for teaching and learning management.

\section{Desirable State of PPICC: Purpose and Processing on Ideation and Creative Innovations for Competency Innovator:}

Desirable State of Purpose found that the overall level is the highest $(\bar{X}=4.520$, S.D. $=0.55)$ and when considered each side respectively as follows: Insatiable Curiosity, Stamina, Divergent Thinking, Respect for Innovators, Courage, Compelling Leadership.

Desirable State of Processing found that the overall level is the highest $(\overline{\mathrm{X}}=4.656$, S.D. $=0.56)$ and when considered each side respectively as follows: Use Technology to Facilitate Teaching and Learning, Establish University Industry Linkages, Facilitate University to Work Transition. Desirable State of Discovery Skill found that the overall level is the highest $(\overline{\mathrm{X}}=4.525$, S.D. $=0.77)$ on Ideation Innovations and when considered each side respectively as follows: Critical Mind, Productive Mind, Creative Mind, Productive Mind.

Desirable State of Creating Innovations found that the overall level is the highest $(\overline{\mathrm{X}}=4.567$, S.D. $=0.55)$ and when considered each side respectively as follows: Put to other Uses, Substitute Combine, Magnify, Minimize, Eliminate, Adapt, Rearrange, Reserves.

Desirable State of Competency Innovator found that the overall level is the high $(\overline{\mathrm{X}}=4.125$, S.D. $=0.87)$ and when considered each side respectively as follows: Ideation, Integration, Implementation, Imagination, Inspiration.

Desirable State Current State of Goals of successful factors for the development of innovation undergraduate courses in private universities found that the overall level is the highest $(\overline{\mathrm{X}}=4.555$, S.D. $=0.68)$ and when considered each side respectively as follows:

Develop teacher for Professional Teachers was at a moderate level and when considered each side respectively as follows: Inspirer, Advocate, Confidant, Friend, Mentor, Leader, Illumination.

Professional Teachers found that the overall level is the highest $(\bar{X}=4.568$, S.D. $=0.48)$ and when considered each side respectively as follows: - Subject matt and Pedagogical, Knowledge Skill for Collaboration and problem- solving creative skill, Learning Teaching and Assessment methods. Learning and teaching management overall result was at a moderate level $(\overline{\mathrm{X}}=4.560$, S.D. $=0.54)$ and when considered each side respectively as follows: Create interaction in learning through connection and networking Create a fun learning concept - Create an assessment model that reflects the results - Create strengthening and supporting factors.

Learning processes for the management of the environment for teaching and learning found that the overall level is the highest $(\overline{\mathrm{X}}=4.540$, S.D. $=0.64)$ and when considered each side respectively as follows: - Develop teachers to have different characteristics for the development of innovation Define how to teach teachers to be professional teachers teaching and learning process -Environment management for teaching and learning management.

\section{The priority needs index of PPICC: Purpose and Processing on Ideation and Creative Innovations for Competency Innovator The first priority need index}

The priority needs index of Purpose (PNIModified $=0.219$ ) The first priority need index fell on Stamina, Insatiable Curiosity, Compelling Leadership, Respect for Innovators, Courage, Divergent Thinking

The priority needs index of Processing (PNIModified = 0.265) The first priority need index fell on Establish University - Industry Linkages Use Technology to Facilitate Teaching and Learning, Facilitate University to Work Transition.

The priority needs index of Discovery Skill on Ideation Innovations (PNIModified $=0.335$ ) The first priority need index fell on Creative Mind, Critical Mind, Productive Mind, Productive Mind.

The priority needs index of Creating Innovations (PNIModified $=0.293$ ) The first priority need index fell on Put to other Uses, Combine, Substitute, Magnify, Minimize, Eliminate, Reserves, Adapt, Rearrange.

The priority needs index of Competency Innovator (PNI Modified $=0.242$ ) The first priority need index fell on Ideation, Imagination, Inspiration, Implementation, Integration.

The priority needs index Current State of Goals of successful factors for the development of innovation undergraduate courses in private universities and when considered each side respectively as follows:

Develop teacher for Professional Teachers (PNI Modified = 0.291) The first priority need index fell on Inspirer, Advocate, Confidant, Mentor, Leader, Illumination, Friend. Professional Teachers (PNIModified $=0.295$ ) The first priority need index fell on Skill for Collaboration and problem- solving creative skill, Subject matt and Pedagogical Knowledge, Learning Teaching and Assessment methods.

Learning and teaching management $($ PNIModified $=0.264$ ) The first priority need index fell on Create interaction in learning through connection and networking -Create a fun learning concept - Create an assessment model that reflects the results - Create strengthening and supporting factors. 
Learning processes for the management of the environment for teaching and learning.(PNIModified $=0.290$ ) The first priority need index fell on Establish University - Industry Linkages - Use Technology to Facilitate Teaching and Learning -Facilitate University to Work Transition.

\section{Discussions}

Based on the results, the current state is at a moderate level while the desirable state is at a highest level, suggesting the needs for PPICC: Purpose and Processing on Ideation and Creative Innovations for Competency Innovator can be used as a policy to implement an educational management development plan to focus on the students' innovation teaching and learning process from the development of teachers to develop environment [12][13][14]. According to Kylliäinen, the concept of innovation is based on finding out from critical problem, choosing a problem that suits your abilities strategy and culture, formulating strategies for developing the most possible innovations to address problems, taking advantage of the platform to access technology information, create a culture of cooperation, and understanding that innovation is a complicated business [15]. According to Manyat Rujivit, Marut Pachotasingha, the academic service of academics in higher education institutions should cover the implementation of innovation in society for improving the quality of people's life in the community and to prevent innovation from emerging. Bringing innovation gained from creativity through the graduate production process in the university should be used for career promotion in order to reduce the inequality of people of society [16].

For desirable conditions, the overall level of Processing is at the highest and when considered on each side respectively as follows: Use Technology to Facilitate Teaching and Learning in which the university should manage with technology in teaching to develop learners' innovation. According to Abhipriya Roy, recent advancements in educational technologies have yielded positive results in our education sector. New educational technology supports both the teaching and learning processes. Technology has digitized classrooms through digital learning tools like, computers, iPads, smartphones, smart digital white boards. It has expanded course offerings, and has increased student's engagement and motivation towards learning. This paper deals with the problems faced by teachers while teaching English in the traditional methods. It propounds five new language games to teach syntax structures to the learners by incorporating technology [17]. For the need of the development of innovative skills for the learners of educational institutions found that Discovery Skill of Ideation Innovations has the highest need and when considered on each side as follows: Creative Mind which can be seen that providing students with the ability to discover themselves and to develop thinking skills is a necessary point for developing competence in thinking and creating innovation in various ways as "Design Thinking is a human centred approach to innovation that draws from the designer's toolkit to integrate the needs of people, the possibilities of technology, and the requirements for business success." "Design is a complex process that is implemented in different disciplines with many factors in mind; one of these factors is the target of the design process. Generally, there are three design process paradigms based on this target; technology-driven design, human-centred design and environmentally sustainable design.

Based on this categorization, human-centred design can be defined as the process that places human needs and limitations in a higher priority compared with other targets during the Design Thinking and production differential stages" Design Thinking has become a major methodology, presently running ahead in the expectations of what it can deliver. Design Thinkers need to take a step back and rethink how to take this concept forward. The Design Thinking community will then follow and respond. There is hope, well beyond a glimmer that we are seeing Design Thinkers recognize they need to step up their game, and take the concept to a more strategic position at system level. This will mean that Design Thinking will change in the future into a greater, fuller "thinking" mindset that can be applied to more complex problems at an organizational level, and contribute to numerous challenges organizations are facing today. It needs to evolve, otherwise it simply fades away, into the background of being just another interesting tool. It certainly needs to mature way beyond a one frame thinking concept to achieve this. DT needs to go beyond being a thinking method for products, services, and customer experience. System level thinking is where the future of design is focused, and where much of the current confusion lies, as we are in the middle of these changes. Investing time in defining the desired outcome is critical in any Design Thinking journey. And the same may hold true for the the journey of the method itself. These are exciting times! We are witnessing how one of the most promising - since human centered - innovation methods is evolving towards becoming essential for organizational thinking

\section{References}

[1] Avvisati, Francesco \& Jacotin, Gwenaël \& Vincent-Lancrin, Stéphan, "Educating Higher Education Students for Innovative Economies: What International Data Tell Us," Tuning Journal for Higher Education, 1, 223, 10.18543/tjhe-1(1)-2013, pp. 223240, 2013.

[2] Edwards-Schachter, M., García-Granero, A., Sánchez-Barrioluengo, M., QuesadaPineda, H., \& Amara, N., "Disentangling competences: Interrelationships on creativity, innovation and entrepreneurship. Thinking Skills and Creativity," vol. 16, pp. 27-39., 2015, Retrieved from https://doi.org/10.1016/j.tsc.2014.11.006.

[3] Vila, L.E., Perez, P.J. and Morillas, F.G., "Higher education and the development of competencies for innovation in the 
workplace", Management Decision, vol. 50, no. 9, pp. 1634-164, 2012.

[4] Avvisati, Francesco \& Jacotin, Gwenaël \& Vincent-Lancrin, Stéphan, "Educating Higher Education Students for Innovative Economies: What International Data Tell Us," Tuning Journal for Higher Education, 1, 223, 10.18543/tjhe-1(1)-2013, pp. 223240, 2013.

[5] Trilling, B., \& Fadel, C., "21st Century Skills: Learning for Life in Our Times", San Francisco, CA: John Wiley \& Sons, 2009.

[6] Ministry of Education, "Student development to Thailand 4.0," 2016, Retrieved from https://www.moe.go.th/\%E0\%B8\%81\%E0 $\%$ B8\%B2\%Е0\%B8\%A3\%Е0\%B8\%9E\% Е0\%В8\%В1\%Е0\%В8\%92\%Е0\%В8\%99 $\%$ Е0\%В8\%B2\%Е0\%В8\%99\%Е0\%В8\%В 1\%Е0\%B8\%81\%Е0\%B8\%A8\%Е0\%B8\% B6\%Е0\%B8\%81\%Е0\%B8\%A9\%Е0\%B8 $\%$ В2\%Е0\%B8\%AA\%Е0\%B8\%B9\%Е0\% B9\%88-thailand-4-0

[7] Chickering A.W. and Reisser, L., "Education and Identity, 2nd Edition, San Francisco", CA: Jossey-Bass, 1993.

[8] Kylliäinen, J., "Types of Innovation - The Ultimate Guide with Definitions and Examples," 2019, Retrieved from https://www.viima.com/blog/types-ofinnovation,

[9] Creative \& Design Center (TCDC), "Return happiness to patients using service design: the further steps of Bamrungraj International Hospital," 2017, Retrieved from http://www.tcdc.or.th/articles/others/ 21956 / \# Return happiness to patients using- Service-De-sign - the further steps of Bamrungraj International Hospital From https://www.ideo.com/post/designthinking-in-harvard-business-review https://www.ideo.com/post/the-power-ofdesign-in-businessweek

[10] Nuchjaree Kitwan, "Design Thinking: New Perspectives of the Thai Health System," Journal of Nursing Council, vol. 33, no. 1, pp.5-14, 2018.
[11] Dyer, J., Gregersen, H. \& Christensen, C., "The Innovator's DNA: Mastering the Five Skills of Disruptive Innovators," Harvard Business School Press, 2011.

[12] Avvisati, Francesco \& Jacotin, Gwenaël \& Vincent-Lancrin, Stéphan, "Educating Higher Education Students for Innovative Economies: What International Data Tell Us," Tuning Journal for Higher Education, $1,223,10.18543 /$ tjhe-1(1)-2013, pp. 223240, 2013.

[13] Edwards-Schachter, M., García-Granero, A., Sánchez-Barrioluengo, M., QuesadaPineda, H., \& Amara, N., "Disentangling competences: Interrelationships on creativity, innovation and entrepreneurship. Thinking Skills and Creativity," vol. 16, pp. 27-39., 2015, Retrieved from https://doi.org/10.1016/j.tsc.2014.11.006.

[14] Vila, L.E., Perez, P.J. and Morillas, F.G., "Higher education and the development of competencies for innovation in the workplace", Management Decision, vol. 50, no. 9, pp. 1634-164, 2012.

[15] Kylliäinen, J., "Types of Innovation - The Ultimate Guide with Definitions and Examples," 2019, Retrieved from https://www.viima.com/blog/types-ofinnovation,

[16] Manyat Rujivit, Marut Pachotasingha, "Strategies for Incubating Innovation in Higher Education," 2018, Retrieved from https://www.matichon.co.th/education/new s_894745

[17] Abhipriya, Roy. "TECHNOLOGY IN TEACHING AND LEARNING," MPhil Research Scholar English Department Christ University, Bangalore, India JETIR April 2019, vol. 6, no. 4, Retrieved from www.jetir.org (ISSN-2349-5162) 